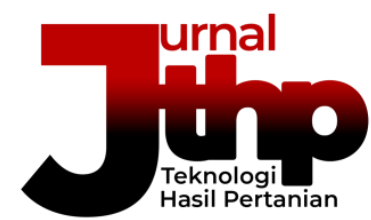

Jurnal Teknologi Hasil Pertanian. 14(2), 75-83

URL: https://jurnal.uns.ac.id/ilmupangan/article/view/48363

DOI: https://doi.org/10.20961/jthp.v14i2.48363

ISSN 1979-0309 (Online) 2614-7920 (Print)

\title{
POTENSI EKSTRAK KAYU MANIS (Cinnamomum burmannii) SEBAGAI SENYAWA ANTIMIKROBIA PADA EDIBLE FILM PATI SUKUN (Artocarpus communis)
}

\author{
THE POTENTIAL OF CINNAMON (Cinnamomum burmannii) AS ANTIMICROBIAL AGENT \\ IN BREAD FRUITS (Artocarpus communis) STARCH EDIBLE FILM
}

\author{
Merkuria Karyantina, Nanik Suhartatik, Fajar Eko Prastomo \\ Program Studi Teknologi Hasil Pertanian, Fakultas Teknologi dan Industri Pangan, Universitas Slamet Riyadi \\ Surakarta, Jl. Sumpah Pemuda 18 Joglo, Surakarta, Jawa Tengah, Indonesia, 57136 \\ Email: kar_yantina@yahoo.com
}

Diserahkan [6 Februari 2021]; Diterima [17 Juli 2021]; Dipublikasi [2 September 2021]

\begin{abstract}
Issues about environmental damage caused by the presence of plastic-based packaging materials require the development of eco-friendly packaging materials. Breadfruit starch contains amylose which has the potential to be developed into natural packaging materials, or edible films. Another function of packaging was to protect food ingredients from damage, one of which was microbiological damage. This study aimed to determine the level of breadfruit starch to produce edible films that meet the standards and to determine the ability of cinnamon extract to inhibit the activity of tested bacteria. The study was conducted using a factorial completely randomized design with 2 factors, namely the concentration of breadfruit starch and the concentration of cinnamon. The results showed that breadfruit starch can be used at a level of $6 \%$ which will produce edible film with a tensile strength of up to $6.37 \mathrm{MPa}$ and a thickness of $0.23 \mathrm{~mm}$. Cinnamon extract were able to inhibit the growth of Escherichia coli and Staphylococcus aureus bacteria. Both breadfruit starch and cinnamon extract have the potential to be developed as natural ingredients in the process of making edible films.
\end{abstract}

Keywords: antimicrobial; breadfruit starch; cinnamon; edible film

\section{ABSTRAK}

Isu-isu tentang kerusakan lingkungan disebabkan karena adanya bahan pengemas berbahan dasar plastik menuntut untuk dikembangkannya bahan pengemas ramah lingkungan. Pati sukun mengandung amilosa yang berpotensi untuk dikembangkan menjadi bahan pengemas alami, atau edible film. Fungsi pengemas yang lain adalah untuk melindungi bahan makanan dari kerusakan, salah satunya adalah kerusakan mikrobiologis. Penelitian ini bertujuan untuk menentukan kadar pati sukun yang tepat untuk menghasilkan edible film yang memenuhi standar dan menentukan kemampuan ekstrak kayu manis dalam menghambat aktivitas bakteri uji. Penelitian dilakukan menggunakan rancangan acak lengkap faktorial dengan 2 faktor, yaitu konsentrasi pati sukun dan konsentrasi kayu manis. Hasil menunjukkan bahwa pati sukun dapat digunakan pada kadar 6\% dan kayu manis 1\% menghasilkan edible film dengan kuat tarik mencapai 6,37 MPa dan ketebalan 0,23 mm. Ekstrak kayu manis pada edible film terbukti mampu menghambat pertumbuhan bakteri Eschericia coli dan Staphylococcus aureus berpotensi untuk dikembangkan sebagai bahan alami dalam proses pembuatan edible film.

Kata kunci: antimikrobia; pati sukun; kayu manis; edible film

Saran sitasi: Karyantina, M., Suhartatik, N., \& Prastomo, F. E. 2021. Potensi Ekstrak Kayu Manis (Cinnamomum burmannii) Sebagai Senyawa Antimikrobia pada Edible film Pati Sukun (Artocarpus communis). Jurnal Teknologi Hasil Pertanian, 14(2), 75-83. https://doi.org/10.20961/jthp.v14i2.48363 


\section{PENDAHULUAN}

Plastik sebagai bahan pengemas menimbulkan permasalahan lingkungan untuk ratusan tahun ke depan. Ini disebabkan karena sifat plastik yang tidak dapat didegradasi oleh mikrobia yang ada di dalam tanah. Selain itu, plastik tersusun dari monomer yang bersifat karsinogen dan dan dapat bereaksi dengan makanan sehingga secara tidak langsung, dapat memberikan efek merugikan bagi kesehatan (Cereda, 2000). Penggunaan edible film sebagai bahan dasar pengganti plastik bisa digunakan sebagai alternatif karena edible film dapat diurai oleh mikrobia dalam tanah. Selain itu, edible film juga terbuat dari bahan organik yang dapat langsung dikonsumsi dan tidak membahayakan tubuh. Edible film biasanya dibuat dari bahan yang bersifat hidrofil dan membentuk lapisan tipis. Edible film bisa dibuat dari pati atau tepung maizena (Kusumawati \& Putri., 2013 ; Santoso et al., 2018); pati singkong (Saleh et al., 2017); sagu (Polnaya et al., 2016); tepung labu kuning (Widodo et al., 2019); pati kimpul (Warkoyo et al., 2014), alginate (Parreidt et al., 2018), dan lain-lain. Pati sukun digunakan dalam penelitian ini karena penggunaan sukun sampai saat ini belum banyak dilakukan. Sukun biasa dikonsumsi dengan cara digoreng, direbus, atau dikukus. Sukun juga telah diuji kemampuan sebagai bahan baku dalam proses pembuatan cookies (Marta et al., 2017; brownies (Marta et al., 2017); ataupun mie kering (Safriani et al., 2013).

Sukun berpotensi untuk dikembangkan sebagai bahan baku dalam proses pembuatan edible film karena kandungan pati (amilosa) yang tinggi (Masita et al., 2017) dan produksinya yang melimpah di Indonesia. Sukun sebagai sumber patinya karena kandungan patinya yang cukup tinggi yaitu sebesar $60 \%$, pemanfaatannya belum optimal, serta jumlahnya melimpah hampir di setiap daerah. Penelitian telah dilakukan oleh Setiani et al., (2013) yaitu edible film menggunakan pati sukun dan kitosan dapat memberikan hasil yang cukup baik, dengan formulasi pati sukun-kitosan 6:4 dengan nilai water uptake sebesar $212,98 \%$, nilai kuat tarik sebesar 16,34 MPa, nilai elongasi sebesar $6,00 \%$ dan modulus young sebesar 2,72 MPa. Pati sukun telah dimanfaatkan dalam pembuatan edible film oleh peneliti lain yaitu Rizky (2105), Rozalina \& Yusbarina, (2017), Nofiandi et al., (2016) dan Putra et al., (2017), dimana menunjukkan potensi pati sukun dalam pembuatan edible film.

Jenis kemasan yang termasuk dalam edible film termasuk dalam jenis kemasan yang ramah lingkungan karena mudah diurai oleh mikrobia. Bahan hidrofilik yang biasa digunakan sebagai bahan dasar pembuatan edible film adalah pati (karbohidrat) atau protein. Komponen utama penyusun edible film terdiri dari 3 bagian, yaitu hidrokoloid, lipida, dan komposit. Edible film harus dapat berfungsi sebagai penghambat perpindahan gas $\mathrm{O}_{2}, \mathrm{CO}_{2}$, dan lipid. Edible film yang dihasilkan juga harus mampu menahan tekanan fisik mekanik agar bisa melindungi bahan pangan dari tekanan, benturan, serta guncangan yang mungkin terjadi (Julianti dan Mimi, 2006).

Salah satu kelemahan edible film yang dibuat dari bahan berpati adalah tingkat kemudahannya untuk mengalami kerusakan karena mudah diurai oleh mikrobia. Bahan plastik sendiri mengandung senyawa antimikrobia alami yang timbul karena proses pembuatan, yaitu vinil klorida yang bersifat karsinogen. Senyawa biofilm yang mengandung senyawa antimikrobia juga banyak dikembangkan,seperti di negara Jepang yang telah mengembangkan plastik dengan senyawa antimikrobia ZnPT (Pittol et al., 2017). Senyawa ini bahkan mempunyai kemampuan untuk menghambat pertumbuhan bakteri Staphylococcus aureus, Eschericia coli, Aspergillus sp., dan bakteri uji lainnya. Senyawa berbahaya yang ada dalam plastik dan membahayakan tubuh adalah vinil klorida. Senyawa ini dapat bermigrasi ke dalam makanan pada suhu tertentu sehingga plastik tidak disarankan penggunaannya pada makanan yang panas (Brandt-Rauf et al., 2012).

Pengembangan senyawa edible film dengan senyawa antimikrobia alami dikembangkan dengan tujuan untuk mengatasi kekurangan-kekurangan pada 
kemasan plastik (polimer). Kemasan ideal yang diinginkan adalah kemasan dengan tingkat transparansi tertentu, ketebalan, elastisitas, dan juga mempunyai kemampuan sebagai antimikrobia. Penggunaan senyawa antimikrobia pada edible film juga pernah dilakukan oleh Mulyadi et al (Mulyadi et al., 2016) yang menggunakan ekstrak gliserol daun beluntas pada produk ikan nila. Hasil menunjukkan bahwa ekstrak beluntas $20 \%$ mampu memberikan nilai penghambatan terhadap bakteri uji sebesar 5,92 mm. Baek dan koleganya (Baek et al., 2018) juga telah melakukan pembuatan film yang terbuat dari alginat dengan penambahan minyak atsiri dari kayu manis. Hasil menunjukan bahwa minyak esensial dari kayu manis dapat menghambat pertumbuhan bakteri uji (E.coli O157:H7, Salmonella typhimurium, $S$. aureus, dan Listeria monocytogenes.

Kayu manis mengandung komponen bioaktif yang disebut sinamaldehida. Minyak atsiri hasil esktraksi etanol kayu manis mempunyai kemampuan untuk menghambat pertumbuhan E.coli, S. aureus, dan Candida albicans dengan daya hambat yang lebih besar daripada ampisilin, streptomisin, amfoterin, dan kloramfenikol (Fadhlina et al., 2014). Kayu manis dipilih sebagai sumber senyawa antimikrobia alami karena tidak mempunyai rasa yang dikhawatirkan akan mengganggu makanan yang dikonsumsi namun juga mengandung senyawa aroma yang dapat memperbaiki aroma makanan. Kayu manis banyak digunakan dalam masakan asli Indonesia karena aromanya yang lembut. Penelitian ini bertujuan untuk menentukan prosentase pati sukun sebagai bahan dasar dalam pembuatan edible film dan menentukan jumlah penambahan ekstrak kayu manis yang tepat untuk menghambat pertumbuhan mikrobia. Bahan alami yang digunakan sebagai sumber senyawa antimikrobia adalah kayu manis (Cinnamomum burmannii). Hasil penelitian ini diharapkan dapat digunakan sebagai rujukan dalam pengembangan bahan pengemas ramah lingkungan dan aman bagi kesehatan tubuh karena terbuat dari senyawa alami. Pengujian edible film antara lain kuat Tarik (Setiani et al., 2013b), ketebalan (Rusli et al., 2017), transparansi (Bao et al., 2009), dan kemampuan untuk menghambat pertumbuhan E. coli dan $S$. aureus (Miksusanti et al., 2013)

\section{METODE PENELITIAN}

\section{Bahan}

Buah sukun dan kayu manis diperoleh pasar tradisional di kota Surakarta. Bahan kimia yang digunakan meliputi meliputi gliserol (Oxoid, Singapura), carboxymethylcellulose (CMC, Sigma) bakteri uji (S.aureus FNCC 0047 dan E. coli FNCC0091) diperoleh dari Food and Nutrition Culture Collection (FNCC) Pusat Studi Pangan dan Gizi, Universitas Gadjah Mada Yogyakarta. Media nutrient agar (Oxoid) diperoleh dari distributor lokal.

\section{Tahapan Penelitian}

\section{Pembuatan pati sukun}

Buah sukun mengkal (masak pohon dan daging buah berwarna putih) dibeli di pasar tradisional sekitar. Proses pembuatan pati sukun dilakukan mengacu pada penelitian yang dilakukan oleh Triwarsita et al., (2013) dengan sedikit modifikasi. Buah sukun dibersihkan, dikupas, dicuci dan dipotong dengan ketebalan $\pm 1 \mathrm{~cm}$ dan direndam dalam larutan garam $0,1 \%$ selama 1 jam. Setelah dicuci bersih, potongan sukun kemudian dihaluskan menggunakan blender (Miyako, Indonesia) dan disaring menggunakan kain saring. Filtrat kemudian didiamkan selama 12 jam dan dipisahkan fraksi airnya. Endapan yang terjadi kemudian dikeringkan menggunakan oven (Memmert) dengan suhu $\pm 40^{\circ} \mathrm{C}$ selama $10 \mathrm{jam}$. Hasil pengeringan kemudian dihancurkan menggunakan blender dan diayak menggunakan ayakan berukuran 80 mesh. Modifikasi yang dilakukan adalah pada alat cetakan yang digunakan dan lama waktu filtrat didiamkan dimodifikasi menjadi 12 jam, bukan 24 jam.

\section{Pembuatan Pembuatan ekstrak kayu manis dimodifikasi}

Kayu manis bubuk sebanyak 10 gram dimasukkan ke dalam erlenmeyer kemudian ditambahkan aquades sampai $100 \mathrm{ml}$, larutan dipanaskan pada suhu $60^{\circ} \mathrm{C}$ selama 60 menit dengan menggunakan waterbath. Larutan 
disaring dan disentrifugasi pada kecepatan 4000 rpm selama 15 menit dan diambil filtratnya. Filtrat langsung digunakan sebagai tambahan dalam pembuatan edible film (Yulia, et al., 2011). Modifikasi yang dilakukan adalah volume pengerjaannya.

\section{Pembuatan edible film}

Edible film dibuat dengan cara membuat suspensi pati dengan konsentrasi 4, 5, dan $8 \%$ (b/v) sesuai perlakuan. Suspensi kemudian dipanaskan hingga mendidih menggunakan hot plate yang dilengkapi magnetic stirrer selama 45 menit hingga mencapai suhu gelatinisasi $\left(70-75^{\circ} \mathrm{C}\right)$. Setelah mendidih, tambahkan $2 \mathrm{ml}$ gliserol dan carboxy methyl cellulose (CMC) 0,25 g. Pemanasan dilanjutkan selama 10 menit kemudian didinginkan dengan cara didiamkan pada suhu kamar. Suspensi yang sudah dingin kemudian ditambah dengan ekstrak kayu manis dengan konsentrasi sesuai dengan perlakuan $(1 ; 1,5 ;$ dan $2 \%)$ terhadap volume cairan yang ditambahkan dalam proses pembuatan edible film dan diaduk hingga homogen. Suspensi diambil sebanyak $15 \mathrm{ml}$ dan dituang pada cetakan (petridish diameter $8 \mathrm{~cm}$ ) didiamkan pada suhu ruang \pm 24 jam. Pengeringan dilakukan dengan oven (Memmert) pada suhu $46^{\circ} \mathrm{C}$ selama 15 jam. Lapisan edible film kemudian dikeluarkan dan didiamkan pada suhu ruang $\left(25^{\circ} \mathrm{C}\right)$ selama 30 menit (Huri \& Nisa, 2014).

\section{Rancangan Percobaan}

Penelitian menggunakan rancangan acak lengkap faktorial dengan 2 faktor perlakuan, yaitu konsentrasi pati sukun $(4,5$, dan $8 \%$ (b/v)) dan banyaknya ekstrak kayu manis yang ditambahkan (1; 1,5 ; dan 2\%). Parameter yang diuji adalah kadar air (SNI01-23542-2015), kuat Tarik, ketebalan, transparansi, dan kemampuan untuk menghambat pertumbuhan $E$. coli dan $S$. aureus. Data yang diperoleh kemudian diuji ANOVA SPSS for windows. Jika ada beda nyata, dilanjutkan dengan Uji Tukey dengan taraf signifikansi 5\%. Pengukuran transparansi edible film dilakukan menggunakan spektrofotometer pada panjang gelombang $(\lambda) 546 \mathrm{~nm}$ sesuai dengan metode yang dijelaskan oleh Bao et al., (2009).
Edible film dengan ketebalan tertentu (mm) dipotong secukupnya dan dimasukkan ke dalam sel uji. Nilai absorbansi pada panjang gelombang $546 \mathrm{~nm}$ dan dimasukan dalam persamaan.

\section{HASIL DAN PEMBAHASAN}

\section{Karakteristik Edible film Pati Sukun Dengan Penambahan Ekstrak Kayu Manis}

Hasil analisis kadar air edible film menunjukkan bahwa semakin tinggi penambahan pati sukun dan ekstrak kayu manis, kadar air cenderung semakin menurun walaupn secara statisktik tidak berbeda nyata, walaupun tidak terdapat pengaruh nyata antar perlakuan berdasarkan hasil analisis statistik (Tabel 1). Pati merupakan komponen makromolekul yang mempunyai kemampuan untuk menyerap air. Pati bersama dengan air serta dengan adanya pemanasan, dapat membentuk gel. Semakin banyak gugus hidroksil yang ada pada pati, semakin besar pula kemampuannya untuk menahan air (Wiramukti, 2012).

Kadar air edible film semakin turun dengan semakin menurunnya jumlah pati yang ditambahkan. Pati merupakan senyawa pembentuk gel. Kemampuan pati untuk menahan air berhubungan dengan kadar amilosanya. Komposisi amilosa dan amilopektin akan mempengaruhi kualitas edible film yang dihasilkan. Kadar air edible film akan semakin menurun dengan bertambahnya konsentrasi ekstrak kayu manis. Ekstrak kayu manis yang ditambahkan dalam edible film ini berbentuk filtrat, dan tidak melalui proses penghilangan total padatan terlarut, kadar air edible film berpengaruh tidak nyata. Padatan terlarut dalam filtrat kayu manis mampu mengikat air, sehingga kadar air mengalami penurunan sejalan dengan bertambahnya ekstrak kayu manis yang digunakan. Kadar air yang menurun dipengaruhi oleh penambahan pati sukun dimana berhubungan dengan kemampuan pembentukan gel serta padatan pada ekstrak kayu manis yang semakin meningkat seiring dengan meningkatnya konsentrasi kayu manis. 
Tabel 1 Kadar air, ketebalan, transparansi, dan kuat tarik edible film pati sukun dengan perlakuan penambahan ekstrak kayu manis

\begin{tabular}{|c|c|c|c|c|c|}
\hline \multirow{2}{*}{$\begin{array}{l}\text { Konsentrasi } \\
\text { pati sukun } \\
(\%, \mathrm{~b} / \mathrm{v})\end{array}$} & \multirow{2}{*}{$\begin{array}{l}\text { Konsentrasi } \\
\text { kayu manis } \\
(\%, \mathrm{v} / \mathrm{v})\end{array}$} & \multicolumn{4}{|c|}{ Parameter Uji } \\
\hline & & $\begin{array}{c}\text { Kadar air } \\
(\%)\end{array}$ & $\begin{array}{l}\text { Ketebalan } \\
(\mathrm{mm})\end{array}$ & $\begin{array}{c}\text { Transparansi } \\
(\%)\end{array}$ & Kuat Tarik (MPa) \\
\hline \multirow{3}{*}{4} & 1 & $22,07 \pm 1,286^{\mathrm{a}}$ & $0,22 \pm 0,131^{\mathrm{a}}$ & $0,17 \pm 0,045^{\mathrm{a}}$ & $2,68 \pm 0,255^{\mathrm{ab}}$ \\
\hline & 1,5 & $21,13 \pm 1,156^{\mathrm{a}}$ & $0,13 \pm 0,041^{\mathrm{a}}$ & $0,24 \pm 0,086^{\mathrm{a}}$ & $2,38 \pm 0,071^{\mathrm{ab}}$ \\
\hline & 2 & $20,74 \pm 0,844^{\mathrm{a}}$ & $0,14 \pm 0,013^{\mathrm{a}}$ & $0,07 \pm 0,068^{\mathrm{a}}$ & $1,68 \pm 0,636^{\mathrm{a}}$ \\
\hline \multirow{3}{*}{6} & 1 & $20,01 \pm 0,558^{\mathrm{a}}$ & $0,23 \pm 0,099^{a}$ & $0,17 \pm 0,029^{\mathrm{a}}$ & $6,37 \pm 0,742^{c}$ \\
\hline & 1,5 & $16,92 \pm 0,289^{\mathrm{a}}$ & $0,19 \pm 0,080^{\mathrm{a}}$ & $0,17 \pm 0,090^{\mathrm{a}}$ & $3,27 \pm 0,007^{\mathrm{b}}$ \\
\hline & 2 & $17,48 \pm 0,002^{\mathrm{a}}$ & $0,19 \pm 0,058^{\mathrm{a}}$ & $0,26 \pm 0,108^{\mathrm{a}}$ & $1,98 \pm 0,028^{\mathrm{a}}$ \\
\hline \multirow{3}{*}{8} & 1 & $18,32 \pm 0,349^{\mathrm{a}}$ & $0,22 \pm 0,039^{a}$ & $0,22 \pm 0,161^{\mathrm{a}}$ & $10,20 \pm 0,262^{\mathrm{d}}$ \\
\hline & 1,5 & $19,28 \pm 0,546^{\mathrm{a}}$ & $0,19 \pm 0,051^{\mathrm{a}}$ & $0,16 \pm 0,017^{a}$ & $11,81 \pm 0,205^{\mathrm{e}}$ \\
\hline & 2 & $14,38 \pm 0,576^{\mathrm{a}}$ & $0,31 \pm 0,307^{b}$ & $0,23 \pm 0,094^{\mathrm{a}}$ & $6,84 \pm 0,368^{\mathrm{c}}$ \\
\hline
\end{tabular}

Keterangan: Angka yang diikuti notasi yang berbeda pada kolom yang sama menunjukan beda nyata antara perlakuan, begitu juga sebaliknya

Kadar air edible film pada penelitian ini hampir sama dengan kadar air edible film dengan kombinasi tepung lidah buaya, tepung sukun dan ganyong dari penelitian Afriyah et al., (2015) yaitu 9-22\%. Penelitian Rachmayanti, (2015) yaitu edible film berbahan ekstrak kedelai dengan penambahan ekstrak kayu manis 1,5\% memiliki kadar sekitar $13,01 \%$, dimana lebih rendah dari penelitian ini. Saat ini belum ada standar baku untuk kadar air edible film.

Ketebalan edible film pati sukun dengan penambahan ekstrak kayu manis memberikan hasil berpengaruh tidak nyata kecuali untuk perlakuan pati sukun $8 \%$ dengan penambahan kayu manis $2 \%$. Ketebalan edible film dipengaruhi oleh pati sukun yang mengandung amilosa yang tinggi $(27,68 \%)$ yang memiliki kemampuan dalam menyerap air, dibandingkan penambahan esktrak kayu manis. Hasil ini agak sedikit berbeda dengan hasil penelitian-penelitian sebelumnya yang menyatakan bahwa ketebalan edible film dipengaruhi oleh keberadaan komponen bioaktif. Penelitian Afriyah et al., (2015) menunjukkan hal yang serupa, dimana semakin banyak penambahan tepung sukun pada edible film kombinasi lidah buaya, tepung sukun dan ganyong, ketebalan semakin rendah, yang dipengaruhi oleh kemampuan pati dalam menyerap air sehingga menurunkan nilai ketebalan edible film.

Ketebalan edible film harus memenuhi standar tertentu. Film yang terlalu tebal akan membatasi tingkat penggunaannya. standar edible film menurut Japanesse Industrial Standar (JIS) yang menyebutkan ketebalan maksimal tidak lebih dari $0,25 \mathrm{~mm}$. Hal ini berkaitan dengan semakin tingginya konsentrasi komponen penyusun edible film maka akan meningkatkan total padatan sehingga meningkatkan ketebalan edible film (Harris, 2001). Ketebalan edible film tertinggi dicapai pada edible film dengan penambahan pati sukun $8 \%$ dan penambahan ekstrak kayu manis sebesar $2 \%$.

Salah satu parameter penting yang menentukan kualitas edible film adalah kuat tarik. Parameter ini didefinisikan sebagai tarikan maksimum yang dapat dicapai sebelum edible film putus. Kuat tarik juga dapat diartikan sebagai kemampuan edible film untuk meregang dan menahan suatu tekanan (Purwanti, 2010). Berdasarkan penelitian yang dilakukan oleh Warkoyo et al. (2014), semakin banyak amilosa yang ditambahkan dalam pembuatan edible film, semakin tinggi pula kuat tarik edible film yang dihasilkan. Pati sukun merupakan pati dengan kandungan amilosa yang tinggi $27,68 \%$ ), sehingga semakin banyak pati sukun yang ditambahkan dalam edible film, semakin tinggi pula kuat tariknya.

Kuat tarik edible film pati sukun menghasilkan menghasilkan angka tertinggi pada perlakuan $8 \%$ pati sukun dengan penambahan ekstrak kayu manis $1,5 \%$ dengan nilai kuat tarik sebesar 11,81 $\mathrm{MPa}$. Meskipun untuk perlakuan pati sukun 4\% menunjukkan beda tidak nyata untuk penambahan ekstrak kayu manis terhadap kuat tarik edible film, namun secara keseluruhan dapat dilihat bahwa penambahan ekstrak kayu manis mempengaruhi kuat tarik 
edible film yang dihasilkan. Hasil penelitian ini sama dengan apa yang disampaikan oleh Flores et al., (2007); Lim et al., (2010) dan Warkoyo et al., (2014). Penambahan senyawa bioaktif dapat melemahkan daya ikat antar molekul yang ada dalam pati, sehingga akan berpengaruh pada sifat mekaniknya. Parameter edible film menurut Japanesse Industrial Standar (JIS) dalam Nurindra et al., (2015) adalah memiliki ketebalan maksimal 0,25 mm, laju transmisi uap air maksimal $10 \mathrm{~g} / \mathrm{m}^{2} / 24$ jam, kuat tarik minimal 3,92 $\mathrm{MPa}$, dan persen perpanjangan mencapai 5\%. Parameter kuat tarik dan ketebalan edible film pati sukun telah memenuhi standar, namun perlu dilakukan untuk laju transmisi air masih perlu dilakukan uji lebih lanjut.

\section{Kayu Manis Sebagai Senyawa Antimikroba Pada Edible film}

Hasil analisis menunjukkan bahwa semakin banyak konsentrasi ekstrak kayu manis yang ditambahkan, diameter zona jernih menunjukkan tidak berbeda nyata secara statistic (Tabel 2). Komponen aktif pada ekstrak kayu manis diduga mampu menekan pertumbuhan bakteri patogen. Semakin lebar diameter zona jernih menunjukkan bahwa daya hambat edible film semakin kuat. Penelitian ini menunjukkan bahwa pada uji daya hambat terhadap bakteri E.coli FNCC 0091 dan Staphylococcus aureus FNCC 0047 cenderung semakin menurun dengan semakin meningkatnya konsentrasi ekstrak kayu manis, yang dimungkinkan karena efektifitas anti mikrobia kayu manis juga dipengaruhi oleh konsentrasi pati sukun yang digunakan. Penelitian lebih lanjut untuk mempelajari tentang pengaruh konsentrasi pati terhadap daya hambat senyawa bioaktif perlu dilakukan lebih lanjut. Namun diduga bahwa menurunnya daya hambat disebabkan karena adanya faktor pengenceran oleh adanya pati.

Kayu manis atau cinnamon mempunyai kemampuan sebagai antimikroba, antifungi, antivirus, antioksidan, antitumor, penurun tekanan darah, dan kolesterol (Bandara et.al., 2012). Senyawa eugenol dan sinamaldehid yang terdapat dalam kayu manis, memiliki potensi sebagai antibakteri (Niu dan Gilbert, 2004). Konsentrasi pati sukun dan jumlah ekstrak kayu manis tidak memberikan pengaruh nyata terhadap daya hambat ekstrak kayu manis terhadap bakteri uji. E. coli yang merupakan bakteri Gram (-) sedangkan $S$. auereus tergolong dalam bakteri Gram (+). Perbedaan antara kedua golongan bakteri ini terletak pada struktur dinding selnya. Berdasarkan hasil pengujian aktivitas antimikrobia ekstrak kayu manis, penghambatan terhadap kedua jenis bakteri uji menunjukan hasil berbeda tidak nyata. Shan B et al (2007) melaporkan bahwa ekstrak kulit batang cinnamon mampu menghambat pertumbuhan patogen Bacillus cereus, Listeria monocytogenes, S. aureus, E. coli, dan Salmonella anatum.

Tabel 2 Aktivitas antimikroba edible film pati sukun dengan penambahan ekstrak kayu manis

\begin{tabular}{cccc}
\hline $\begin{array}{c}\text { Konsentrasi pati } \\
\text { sukun }(\%, \mathrm{~b} / \mathrm{v})\end{array}$ & $\begin{array}{c}\text { Konsentrasi } \\
\text { kayu manis }(\%,\end{array}$ & \multicolumn{2}{c}{ Daya hambat terhadap $(\mathrm{cm})$} \\
\cline { 3 - 4 } & $\mathrm{v} / \mathrm{v})$ & E.coli & S. aureus \\
\hline & 1 & $1,25 \pm 0,058^{\mathrm{ab}}$ & $1,33 \pm 0,096^{\mathrm{ab}}$ \\
& 1,5 & $1,13 \pm 0,050^{\mathrm{ab}}$ & $1,10 \pm 0,081^{\mathrm{ab}}$ \\
& 2 & $1,15 \pm 0,034^{\mathrm{ab}}$ & $1,28 \pm 0,096^{\mathrm{ab}}$ \\
\hline & 1 & $1,18 \pm 0,050^{\mathrm{ab}}$ & $1,43 \pm 0,096^{\mathrm{b}}$ \\
& 1,5 & $1,28 \pm 0,096^{\mathrm{b}}$ & $1,28 \pm 0,096^{\mathrm{ab}}$ \\
& 2 & $1,13 \pm 0,096^{\mathrm{ab}}$ & $1,38 \pm 0,096^{\mathrm{b}}$ \\
\hline & 1 & $1,05 \pm 0,058^{\mathrm{a}}$ & $1,38 \pm 0,126^{\mathrm{b}}$ \\
& 1,5 & $1,10 \pm 0,082^{\mathrm{ab}}$ & $1,35 \pm 0,058^{\mathrm{b}}$ \\
& 2 & $1,10 \pm 0,183^{\mathrm{ab}}$ & $1,16 \pm 0,050^{\mathrm{ab}}$ \\
\hline
\end{tabular}

Keterangan: Angka yang diikuti notasi yang berbeda pada kolom yang sama menunjukan beda nyata antara perlakuan, begitu juga sebaliknya 
Hasil penelitian ini sesuai dengan hasil penelitian yang disampaikan oleh Nisa dan Triastuti (2014) yang menyampaikan bahwa ekstrak kayu manis mampu menghambat pertumbuhan $E$. coli dan $S$. aureus. Penambahan ekstrak kayu manis ke dalam edible film pati sukun patut dipertimbangkan dan perlu dipelajari lebih lanjut konsentrasi minimal yang harus diberikan, karena ekstrak kayu manis mempunyai kemampuan untuk memberikan kontribusi pada rasa atau aroma bahan pangan.

\section{KESIMPULAN}

Konsentrasi pati sukun yang dapat digunakan untuk menghasilkan edible film yang memenuhi standar adalah $6 \%$ dan penambahan ekstrak kayu manis 1\%. Ekstrak kayu manis $1 \%$ memberikan potensi penghambatan yang paling besar diantara perlakukan lain, dimana mampu menghambat E.coli FNCC 0091 hingga $1,25 \mathrm{~cm}$ sedangkan untuk bakteri uji Staphylococcus aureus FNCC 0047mampu menghambat hingga $1,43 \mathrm{~cm}$. Penelitian untuk menguji kemampuan ekstrak kayu manis dengan konsentrasi yang lebih rendah, perlu dilakukan. Pati sukun berpotensi untuk dikembangkan sebagai bahan dasar dalam proses pembuatan edible film.

\section{DAFTAR PUSTAKA}

Afriyah, Y., Putri, W. D. R., \& Wijayanti, S. D. (2015). Penambahan Aloe vera $L$. dengan Tepung Sukun (Artocarpus communis) dan Ganyong (Canna edulis Ker.) Terhadap Karakteristik Edible Flim. Jurnal Pangan Dan Agroindustri, 3(4), 1313-1324.

Baek, S. K., Kim, S., \& Song, K. Bin. (2018). Characterization Of Ecklonia Cava Alginate Films Containing Cinnamon Essential Oils. International Journal of Molecular Sciences, 19(11). https://doi.org/10.3390/ijms19113545

Bao, S., Xu, S., \& Wang, Z. (2009). Antioxidant Activity And Properties Of Gelatin Films Incorporated With Tea Polyphenol-Loaded

Chitosan Nanoparticles. Journal of the Science of
Food and Agriculture, 89(15), 2692 2700. https://doi.org/10.1002/jsfa.3775

Brandt-Rauf, P. W., Li, Y., Long, C., Monaco, R., Kowali, G., \& Marion, M. J. (2012). Plastics and carcinogenesis: the example of vinyl chloride. Journal of Carcinogenenis, 11(5), PMCID: 3327051.

Cereda, M. P. (2000). Characterization of Edible films of Cassava Starch by Electron Microscopy Caracterização Microscópica de Filmes Comestíveis de Fécula de Mandioca. Methods, December 2017, 91-95.

Fadhlina, A., Binti, I., Susanti, D., \& Taher, M. (2014). Antimicrobial Activity and Synergic Effect of Cinnamomum burmannii's Essential Oil \& its isolated compound (Cinnamaldehyde). International Journal of Advances in Chemical Engineering and Biological Sciences, 1(1), 26-29. https://doi.org/10.15242/ijacebs.c12130 73

Flores, S., Famá, L., Rojas, A. M., Goyanes, S., \& Gerschenson, L. (2007). Physical Properties Of Tapioca-Starch Edible films: Influence Of Filmmaking And Potassium Sorbate. Food Research International, 40(2), 257-265. https://doi.org/10.1016/j.foodres.2006.0 2.004

Harris, H. (2001). Kemungkinan Penggunaan Edible film dari Pati Tapioka untuk Pengemasan Lempuk. Ilmu Ilmu Pertanian Indonesia, 3(2), 99-106.

Huri, D., \& Nisa, F. C. (2014). Pengaruh Konsentrasi Gliserol dan Ekstrak Ampas Kulit Apel Terhadap Karakteristik Fisik dan Kimia Edible film. Jurnal Pangan Dan Agroindustri, 2(4), 29-40.

Kusumawati, Dyah Hayu, Dwi, W., Putri, R., \& Koresponsdensi, P. (2013). Karakteristik Fisik Dan Kimia Edible film Pati Jagung Yang Diinkorporasi dengan Perasan Temu Hitam. Jurnal Pangan dan Agroindustri 1(1), 90-100.

Lim, G. O., Jang, S. A., \& Song, K. Bin. (2010). Physical And Antimicrobial Properties Of Gelidium Corneum/NanoClay Composite Film Containing 
Grapefruit Seed Extract Or Thymol. Journal of Food Engineering, 98(4), 415-420.

https://doi.org/10.1016/j.jfoodeng.2010. 01.021

Marta, H., Cahyana, Y., \& Arifin, H. . (2017). Program Diversifikasi Produk Olahan Berbahan Baku Sukun Sebagai Upaya Peningkatan Usaha Di Kecamatan Rancakalong, Kabupaten Sumedang. Dharmakarya: Jurnal Aplikasi Ipteks Untuk Masyarakat, 6(3), 227-232.

Masita, S., Wijaya, M., \& Fadilah, R. (2017). Karakteristik Sifat Fisiko-Kimia Tepung Sukun (Artocarpus Altilis) dengan Varietas Toddo'puli. Jurnal Pendidikan Teknologi Pertanian, 3, 234-241.

Miksusanti, M., Herlina, H., \& Masril, K. I. (2013). Antibacterial And Antioxidant Of Uwi ( Dioscorea Alata L ) Starch Edible film Incorporated With Ginger Essential Oil. International Journal of Bioscience, Biochemistry and Bioinformatics, 3(4), 354-357. https://doi.org/10.7763/IJBBB.2013.V3. 230

Mulyadi, A. F., Pulungan, M. H., \& Qayyum, N. (2016). Pembuatan Edible film Maizena dan Uji Aktivitas Antibakteri (Kajian Konsentrasi Gliserol Dan Ekstrak Daun Beluntas (Pluchea indica L.). Industria: Jurnal Teknologi Dan Manajemen Agroindustri, 5(3), 149158.

https://doi.org/10.21776/ub.industria.20 16.005.03.5

Nofiandi, D., Ningsih, W., Sofie, A., \& Putri, L. (2016). Pembuatan dan Karakterisasi Edible film dari Poliblend Pati SukunPolivinil Alkohol dengan Propilenglikol sebagai Plasticizer. Jurnal Katalisator, 1(2), 1-12.

Nurindra, A. P., Alamsjah, M. A., \& Sudarno. (2015). Karakteristik Edible film dari pati Propagul Mangrove Lindur (Bruguiera gymnorrhiza) dengan Penambahan Carboxymethyl Cellulose (CMC) sebagai Pemlastis. Jurnal Ilmiah Perikanan Dan Kelautan, 7(2), 1-27.

Parreidt, T. ., Muller, K., \& Schmid, M. (2018). Alginate-Based Edible films and
Coatings for Food Packaging Applications. Foods, 7(170), 1-38. https://doi.org/10.3390/foods7100170

Pittol, M., Tomacheski, D., Simões, D. N., Ribeiro, V. F., \& Santana, R. M. C. (2017). Antimicrobial Performance Of Thermoplastic Elastomers Containing Zinc Pyrithione And Silver Nanoparticles. Materials Research, 20(5), 1266-1273. https://doi.org/10.1590/1980-5373-MR2017-0137

Polnaya, F. J., Ega, L., \& Wattimena, D. (2016). Karakteristik Edible film Pati Sagu Alami dan Pati Sagu Fosfat dengan Penambahan Gliserol. Jurnal Agritech, 347. https://doi.org/10.22146/agritech.16661

Purwanti, A. (2010). Analisis Kuat Tarik dan Elongasi Plastik Kitosan Terplastisasi Sorbitol. Jurnal Teknologi, 3(2), 99106.

Putra, A. D., Johan, V. S., Efendi, R., Studi, P., Hasil, T., Pertanian, J. T., Pertanian, F., \& Riau, U. (2017). Penambahan Sorbitol sebagai Plasticizer dalam Pembuatan Edible film Pati Sukun. JOM Fakultas Pertanian, 4(2), 1-15.

Rachmayanti, W. P. (2015). Karakterisasi Antimicrobial Film dari Ekstrak Kedelai dan Tapioka sebagai Bahan Pengemas Makanan. Skripsi. Jurusan Kimia. Universitas Negeri Semarang

Rizky, P. (2105). Pembuatan Edible film Pati Sukun (Artocarpus Altilis) Termodifikasi dari Proses Asetilasi Menggunakan Asetat Anhidrat. Ready Star 2, 135-142.

Rozalina, M., \& Yusbarina. (2017). Pembuatan Edible film dari Pati Sukun dan Ekstrak Kulit Jeruk. Konfigurasi: Jurnal Pendidikan Kimia Dan Terapan, 1(1), 65-73.

Rusli, A., Metusalach, M., \& Tahir, M. M. (2017). Karakterisasi Edible film Karagenan dengan Pemalstis Gliserol. Jurnal Pengolahan Hasil Perikanan Indonesia, 20(2), 219. https://doi.org/10.17844/jphpi.v20i2.174 99

Safriani, N., Moulana, R., \& Ferizal. (2013). Pemanfaatan Pasta Sukun (Artocarpus 
altilis) pada Pembuatan Mie Kering. Jurnal Teknologi dan Industri Pertanian Indonesia, 5(2), 17-24.

Saleh, F. H., Nugroho, A. Y., \& Juliantama, M. R. (2017). Pembuatan Edible film Dari Pati Singkong Sebagai Pengemas Makanan. Teknoin, 23(1), 43-48. https://doi.org/10.20885/teknoin.vol23.i ss1.art5

Santoso, B., Amilita, D., \& Priyanto, G. (2018). Pengembangan Edible film Komposit Berbasis Pati Jagung dengan Penambahan Minyak Sawit dan Tween 20. Agritech, 38(2), 119-124.

Setiani, W., Sudiarti, T., \& Rahmidar, L. (2013a). Preparasi dan Karakterisasi Edible film Dari Poliblend Pati SukunKitosan. Jurnal Kimia VALENSI, 3(2). 100-109 https://doi.org/10.15408/jkv.v3i2.506

Triwarsita, W. S. T., Atmaka, W., \& Muahammad, D. R. A. (2013).
Pengaruh Penggunaan Edible Coating Pati Sukun (Artocarpus altilis) dengan Variasi Konsentrasi Gliserol Sebagai Plasticizer Terhadap Kualitas Jenang Dodol Selama Penyimpanan. J. Teknosains Pangan, 2(1), 124-132.

Warkoyo, Rahardjo, B., Marseno, D. W., Nugroho, J., \& Karyadi, W. (2014). Sifat Fisik, Mekanik dan Barrier Edible film Berbasis Pati Umbi Kimpul (Xanthosoma sagittifoilum) yang Diinkorporasi dengan Kaliumsorbat. Agritech, 34(01), 72-81. https://doi.org/10.22146/agritech.9525

Widodo, L. U., Wati, S. N., \& Vivi A.P, N. . (2019). Pembuatan Edible film Dari Labu Kuning Dan Kitosan Dengan Lliserol Sebagai Plasticizer. Jurnal Teknologi Pangan, 13(1), 59-65. https://doi.org/10.33005/jtp.v13i1.1511 